\title{
Evaluation of Herbicides for Container-Grown Acerola (Malpighia punicifolia L.) Under Greenhouse Conditions ${ }^{1}$
}

\author{
Jaime González-Ibáñez ${ }^{2}$
}

\begin{abstract}
The use of herbicides alachlor, napropamide, diuron, dalapon, metribuzin, simazine, and terbacil resulted in excellent preemergence control of grass and broadleaf weeds in container-grown acerola plants. A greenhouse experiment was conducted for weed control on acerola to evaluate efficacy and to determine the extent to which acerola would tolerate various concentrations of these herbicides. All herbicides tested reduced weeds substantially after 120 days, with the exception of metribuzin at $1 X$ and $2 X$, which killed the plants. Diuron, terbacil, and simazine caused some yellowing of the leaves at the base of the plants. Results indicate that it is possible to grow acerola in containers for about 120 days with excellent growth and satisfactory control of weeds.
\end{abstract}

\section{INTRODUCTION}

Acerola, (Malpighia punicifolia L.) or West Indian cherry, is a shrub or small tree grown commercially in Puerto Rico. Because of its high ascorbic acid content, acerola has great possibilities to become an important crop in Puerto Rico. Its production in Puerto Rico was 900,000 pounds in 1979 with a farm value of $\$ 1$ million dollars.

The Agricultural Experiment Station of the University of Puerto Rico recommends propagation of acerola by cuttings. After the cuttings are well rooted, they must be transplanted to nursery containers. The young plant should be left in the container in the nursery until several branches are developed, when it is ready for transplanting. This waiting period is from 6 months to 1 year. Previous research ${ }^{3,4,5}$ has demonstrated that weeds compete severely with nursery crops grown in plastic bags. Culti-

\footnotetext{
${ }^{1}$ Manuscript submitted to Editorial Board October 27, 1981.

${ }^{2}$ Associate Biologist, Crop Protection Department, Agricultural Experiment Station, University of Puerto Rico, Río Piedras, P. R. Jesús M. Bravo and Víctor Amador from Nutrilite Products Inc., provided nursery containers and small acerola trees. The author thanks Rafael Montalvo-Zapata, Chemist in Charge of the Pest Control Laboratory of the Agricultural Experiment Station for his unbiased interest and aid during the course of this study.

${ }^{3}$ Cibes-Viadé, H. R., González-lbáñez, J. and Harvey, W. A., 1973. Herbicidal control of weeds in coffee seeded in plastic bags, J. Agric. Univ. P.R. 57 (4): 294-9.

${ }^{4}$ González-lbáñez, J., 1964. The use of preemergence herbicides for weed control around young coffee seedlings, J. Agric. Univ. P.R. 48 (1): 25-31.

${ }^{5}$ González-lbáñez, J., and Cibes-Viadé, H. R., 1970. The effect of various herbicides on growth of Dioscorea composita (Hemsl.) under greenhouse conditions, J. Agric. Univ. P.R. 54 (2): $328-33$.
} 
vation in containers is impossible, and manual weeding on a large scale is expensive.

An experiment was established grown in containers at Río Piedras to determine the degree of weed control provided by various herbicides and the extent to which acerola would tolerate various concentrations.

\section{MATERIALS AND METHODS}

The experiment was conducted at the Río Piedras Research Center of the Agricultural Experiment Station of the University of Puerto Rico to evaluate alachlor (2-chloro-2',6'-diethyl- $\mathrm{N}$-(methoxymethyl) acetanilide), napropamide (2-(a-naphthoxyl)-N,N-diethyl propionamide), diuron (3(3,4-dichlorophenyl)-1,1-dimethylurea), dalapon (2,2-dichloropropionic acid), metribuzin (4-amino-6-(1,1-dimethylethyl)-3-(methylthio)-1,2,4triazine-5(4H)-one), simazine (2-chloro-4,6-biz(ethylamino)-s-triazine),

TABLE 1.-Weeds associated with acerola in the check containers in the greenhouse nursery

\begin{tabular}{lll}
\hline Scientific name & $\begin{array}{c}\text { English } \\
\text { common } \\
\text { name }\end{array}$ & $\begin{array}{c}\text { Spanish } \\
\text { common } \\
\text { name }\end{array}$ \\
\hline Digitaria sanguinalis & crabgrass & pendejuelo \\
Eleusine indica & goose grass & pata de gallina \\
Cyperus rotundus & nutsedge & coquí \\
Mimosa pudica & sensitive plant & moriviví \\
Portulacca oleracea & purslane & verdolaga \\
Phyllanthus niruri & niruri & quinino de pobre \\
Vigna repens & & habilla \\
\hline
\end{tabular}

${ }^{1}$ Botanical synonym: V. luteola (Jacq.) Benth.

and terbacil (3-tert-butyl-5-chloro-6-methyluracil). Ninety-two uniform rooted cuttings of $M$. punicifolia were transplanted August 15, 1980, one per three-gallon black plastic container filled with Naguabo clay loam, with pH 7.11; organic matter, $2.08 \%$; sand, $37.84 \%$; clay, $27.28 \%$; and silt, $34.88 \%$. The cuttings were allowed to grow for two additional weeks until well established. After that period, the 92 acerola plants were divided into 23 groups of 4 individuals. Each group received one of the following herbicides and rates: alachlor, diuron, metribuzin and simazine at 0.5, 1.0 or $2.0 \mathrm{~kg} / \mathrm{ha}$; napropamide at $1.5,3.0$ or $6.0 \mathrm{~kg} / \mathrm{ha}$; dalapon at 1,2 or $4 \mathrm{~kg} /$ ha; and terbacil at $0.4,0.8$ or $1.6 \mathrm{~kg} / \mathrm{ha}$. Two groups of plants were left untreated; one group was weeded each month; and the other group, at the end of the experiment. Stock solutions of each herbicide were prepared and applied directly to the surface of the soil with pipettes.

Treatments were arranged in a randomized block design with 23 treatments and four replications. Weed population and weight data were recorded 40, 80 and 120 days after transplanting. Observations on branch 
number and length were recorded for all plants. The data were statistically analyzed, and treatment means were compared with Duncan's multiple range test.

\section{RESULTS AND DISCUSSION}

Table 1 presents the weeds associated with acerola in the check containers. Table 2 shows the weed counts and weights at 40 days after

TABLE 2.-Control of grass and broadleaf weeds associated with acerola in containers in the greenhouse nursery

\begin{tabular}{lccc}
\hline \multirow{2}{*}{$\begin{array}{c}\text { Herbicide } \\
\text { formulation }\end{array}$} & $\begin{array}{c}\text { Rate } \\
\text { applied }\end{array}$ & \multicolumn{2}{c}{ Weed control data at 40 days } \\
\cline { 3 - 4 } & $k g$ ai $/ h a$ & Weed plants ${ }^{1}$ & Weed weight \\
\hline 1. Alachlor & 0.5 & $4.6 \mathrm{~b}^{2}$ & $g$ \\
2. Alachlor & 1.0 & $-\mathrm{b}$ & $0.8 \mathrm{~b}$ \\
3. Alachlor & 2.0 & $0.3 \mathrm{~b}$ & $-\mathrm{b}$ \\
4. Napropamide & 1.5 & $1.8 \mathrm{~b}$ & $4.0 \mathrm{a}$ \\
5. Napropamide & 3.0 & $0.8 \mathrm{~b}$ & $7.1 \mathrm{a}$ \\
6. Napropamide & 6.0 & $0.3 \mathrm{~b}$ & $0.3 \mathrm{~b}$ \\
7. Karmex & 0.5 & $0.8 \mathrm{~b}$ & $4.8 \mathrm{a}$ \\
8. Karmex & 1.0 & $1.8 \mathrm{~b}$ & $1.1 \mathrm{a}$ \\
9. Karmex & 2.0 & $0.3 \mathrm{~b}$ & $0.3 \mathrm{~b}$ \\
10. Dalapon & 1.0 & $1.3 \mathrm{~b}$ & $2.5 \mathrm{a}$ \\
11. Dalapon & 2.0 & $2.1 \mathrm{~b}$ & $3.8 \mathrm{a}$ \\
12. Dalapon & 4.0 & $1.6 \mathrm{~b}$ & $17.8 \mathrm{a}$ \\
13. Metribuzin & 0.5 & $-\mathrm{b}$ & $-\mathrm{b}$ \\
14. Metribuzin & 1.0 & $-\mathrm{b}$ & $-\mathrm{b}$ \\
15. Metribuzin & 2.0 & $-\mathrm{b}$ & $-\mathrm{b}$ \\
16. Simazine & 0.5 & $-\mathrm{b}$ & $-\mathrm{b}$ \\
17. Simazine & 1.0 & $0.5 \mathrm{~b}$ & $1.5 \mathrm{a}$ \\
18. Simazine & 2.0 & $-\mathrm{b}$ & $-\mathrm{b}$ \\
19. Terbacil & 0.4 & $0.5 \mathrm{~b}$ & $8.4 \mathrm{a}$ \\
20. Terbacil & 0.8 & $-\mathrm{b}$ & $-\mathrm{b}$ \\
21. Terbacil & 1.6 & $-\mathrm{b}$ & $-\mathrm{b}$ \\
22. Check Unweeded & - & $16.8 \mathrm{a}$ & $27.0 \mathrm{a}$ \\
23. Check Weeded & - & & $41.8 \mathrm{a}$ \\
\hline
\end{tabular}

\footnotetext{
${ }^{1}$ Number of weeds per container.

${ }^{2}$ Values in columns followed by the same letter do not differ significantly at the $5 \%$ level compared with Duncan's multiple range test.
}

transplanting the acerola trees. Weeds were counted and weighed at 80 and 120 days when they appeared in the untreated checks. All herbicides tested substantially reduced the weed population. Dalapon, a postemergent herbicide, steadily reduced weed population and weight of grass weeds. Alachlor, napropamide, diuron, dalapon, metribuzin, simazine and terbacil gave virtually complete weed control at 40 days. Weeds were present only in the controls at 80 and 120 days. Metribuzin, applied at 
the rates of 1 and $2 \mathrm{~kg} / \mathrm{ha}, 30$ days after treatment, killed all acerola plants. Furthermore, metribuzin at the rate of $0.5 \mathrm{~kg} / \mathrm{ha}$, caused from slight to mild chlorosis to the leaves. Diuron, terbacil and simazine caused a yellowing of some of the leaves (interveinal chlorosis); the lower leaves were affected more than the new leaves.

Table 3 shows the mean number and length of branches of 165-day-old

TABLE 3.-Effect of certain herbicides on the number and length of branches of 165-day old acerola trees, recorded 120 days after herbicide application

\begin{tabular}{|c|c|c|c|}
\hline \multirow{2}{*}{$\begin{array}{l}\text { Herbicide } \\
\text { formulation }\end{array}$} & \multirow{2}{*}{$\begin{array}{c}\text { Rate } \\
\text { applied }\end{array}$} & \multicolumn{2}{|c|}{ Branches } \\
\hline & & $\begin{array}{l}\text { Average } \\
\text { number }\end{array}$ & $\begin{array}{l}\text { Average } \\
\text { length }\end{array}$ \\
\hline & kgai/ha & & $\mathrm{cm}$ \\
\hline 1. Alachlor & 0.5 & 6.75 ai & $307.54 \mathrm{~b}$ \\
\hline 2. Alachlor & 1.0 & $6.75 \mathrm{a}$ & $375.92 \mathrm{~b}$ \\
\hline 3. Alachlor & 2.0 & $6.00 \mathrm{a}$ & $502.29 \mathrm{a}$ \\
\hline 4. Napropamide & 1.5 & $7.25 \mathrm{a}$ & $416.56 \mathrm{ab}$ \\
\hline 5. Napropamide & 3.0 & $6.75 \mathrm{a}$ & $423.55 \mathrm{ab}$ \\
\hline 6. Napropamide & 6.0 & $7.00 \mathrm{a}$ & $354.33 \mathrm{~b}$ \\
\hline 7. Diuron & 0.5 & $6.25 \mathrm{a}$ & $412.12 \mathrm{ab}$ \\
\hline 8. Diuron & 1.0 & $6.75 \mathrm{a}$ & $340.45 \mathrm{ab}$ \\
\hline 9. Diuron & 2.0 & $6.00 \mathrm{a}$ & $377.83 \mathrm{ab}$ \\
\hline 10. Dalapon & 1.0 & $6.75 \mathrm{a}$ & $438.79 \mathrm{ab}$ \\
\hline 11. Dalapon & 2.0 & $5.25 \mathrm{a}$ & $408.94 \mathrm{ab}$ \\
\hline 12. Dalapon & 4.0 & $7.75 \mathrm{a}$ & 358.14 b \\
\hline 13. Metribuzin & 0.5 & $5.50 \mathrm{a}$ & $307.98 \mathrm{~b}$ \\
\hline 14. Metribuzin & 1.0 & - & - \\
\hline 15. Metribuzin & 2.0 & - & - \\
\hline 16. Simazine & 0.5 & $7.25 \mathrm{a}$ & $444.50 \mathrm{ab}$ \\
\hline 17. Simazine & 1.0 & 5.75 a & $390.93 \mathrm{ab}$ \\
\hline 18. Simazine & 2.0 & $5.75 \mathrm{a}$ & $368.30 \mathrm{~b}$ \\
\hline 19. Terbacil & 0.4 & $5.75 \mathrm{a}$ & $352.43 \mathrm{~b}$ \\
\hline 20. Terbacil & 0.8 & $6.50 \mathrm{a}$ & $404.40 \mathrm{~b}$ \\
\hline 21. Terbacil & 1.6 & $6.50 \mathrm{a}$ & $292.74 \mathrm{ab}$ \\
\hline 22. Check Unweeded & - & $6.50 \mathrm{a}$ & $357.60 \mathrm{~b}$ \\
\hline 23. Check Weeded & 一 & $6.50 \mathrm{a}$ & $393.47 \mathrm{ab}$ \\
\hline
\end{tabular}

${ }^{1}$ Values in columns with a common letter do not differ significantly at the $5 \%$ level compared with Duncan's multiple range test.

trees recorded 120 days after treatment application. Although metribuzin at 1.0 and $2.0 \mathrm{~kg} / \mathrm{ha}$ killed the plants, there was no apparent reduction of growth caused by metribuzin at $0.5 \mathrm{~kg} / \mathrm{ha}$.

All preemergence herbicides controlled grass and broadleaf weeds. This study indicates that grass and broadleaf weeds can be selectively controlled in container nursery plants in the greenhouse with all herbicides at the rates tested, with the exception of metribuzin at 1.0 and $2.0 \mathrm{~kg} / \mathrm{ha}$ and possibly terbacil at 1.6. 


\section{RESUMEN}

Un experimento bajo techo de vidrio se llevó a cabo para evaluar el combate de malezas y la tolerancia del acerolo (Malpighia punicifolia) a los herbicidas alachlor, napropamide, diuron, dalapon, metribuzine, simazine y terbacil. Los resultados fueron como sigue: la densidad poblacional de los yerbajos se redujo sustancialment después de 120 días. A los 80 y 120 días se cosecharon las malezas donde las hubiere; se contaron y pesaron únicamente en los tratamientos testigos. Todas las plantas tratadas con metribuzine en las concentraciones de 1.0 y 2.0 $\mathrm{kg} / \mathrm{ha}$ murieron. Diuron, terbacil y simazine causaron alguna amarillez en las hojas basales. Todos los herbicidas preemergentes controlaron eficazmente tanto las gramíneas como los yerbajos de hoja ancha. Los resultados de pruebas experimentales bajo techo de vidrio, en las que se aplicaron un herbicida posemergente y seis preemergentes, comprobaron que con excepción de metribuzine a 1.0 y $2.0 \mathrm{~kg} / \mathrm{ha}$ es posible obtener un excelente crecimiento de plántulas del acerolo, con un control excelente de los yerbajos, por lo menos durante 120 días. 